\title{
Sperm Morphology and Natural Biomolecules from Marine Snail Telescopium telescopium: a Phylogenetic Perspective
}

\author{
Morfología de los Espematozoides y Biomoléculas Naturales del \\ Caracol Marino Telescopium telescopium: una Perspectiva Filogenética
}

"Uttam Datta; ** Manik Lal Hembram; ${ }^{* * *}$ Subhasis Roy \& ${ }^{* * *}$ Prasenjit Mukherjee

DATTA, U.; HEMBRAM, M. L.; ROY, S. \& MUKHERJEE, P. Sperm morphology and natural biomolecules from marine snail Telescopium telescopium: a phylogenetic perspective. Int. J. Morphol., 28(1):175-182, 2010.

SUMMARY: Biochemical analysis of the cytosol fraction isolated from the ovotestis/spermatheca glands of marine mollusc Telescopium telescopium and it's sperm microtubular structure revealed that relatively similar biomolecules like different enzymes, hormones, minerals and structures of the sperm are also exist in humans. Moreover, antiserum of the cytosol fraction was found to crossreact with the human sperm antigen indicated presence of a common sperm surface antigenicity between these two diversified species. These findings might support and / or hypothesize about the origin and diversification of the vertebrate molecules from its ancestral form (s) from the invertebrates, and basic physiological functions of these ancestral biomolecules including some of the cellular structures plausibly remain the same regardless their structural changes even after evolution.

KEY WORDS: Phylogeny; Telescopium telescopium; Biomolecules; Spermatozoa; Mammal.

\section{INTRODUCTION}

The evolution of successive vertebrate groups from the primitive form has been accompanied by major environmental, taxonomical, biochemical and physiological changes, even in their modes of reproduction, including gametic form. Therefore, phylogenetic studies including spermatozoan morphology, their formation and functions in molluscs are also important in-view of the taxonomical purposes (Franzen, 1970; 1977; 1983; Popham, 1979) which reflects the probable ideas on the phylogenetic evolutions for understanding the biological and /or adaptive significance of the spermatozoa and other cells from the lower animals to higher animals. Hence, physiological, biochemical, structural properties as well as the defense mechanisms of different cells, their nature and interactions in invertebrates are very important in relation to phylogeny and ontogeny to intercept the basic molecular mechanisms that has evolved in mammals through the ages. Therefore, the aim of this study was to synthesize the diverse observation to provide insight into the types of biomolecules present as well as morphological features of the sperm cell from Telescopium telescopium, and cross-reactivity of the spermatheca/ ovotestis cytosol antiserum with human sperm antigen which may pave the way for obtaining some basic informations as plausible aid in the determination of phylogenetic relationship between the mollusc and mammals.

\section{MATERIAL AND METHOD}

Collection of the sample. The univalve marine mollusc Telescopium telescopium (Figure 1) was collected from the muddy estuaries of upper intertidal zone during low tide from Sagar Island (220 19' N; 800 03' E), West Bengal, India, situated at Bay of Bengal of Indian Ocean. Fifty adult snails (apprx. $10 \mathrm{~cm}-11 \mathrm{~cm}$ in length) were collected randomly in the month of June 2007, and brought to laboratory into an open mouth plastic container containing sea water within 4 $\mathrm{h}$ after collection.

\footnotetext{
- Senior Lecturer, Department of Veterinary Gynaecology \& Obstetrics, West Bengal University of Animal and Fishery Sciences, India.

** Ph.D. Fellow, Department of Veterinary Gynaecology \& Obstetrics, West Bengal University of Animal and Fishery Sciences, India.

${ }^{* * * *}$ Senior Research Fellow, Department of Veterinary Surgery and Radiology, West Bengal University of Animal and Fishery Sciences, India.
} 


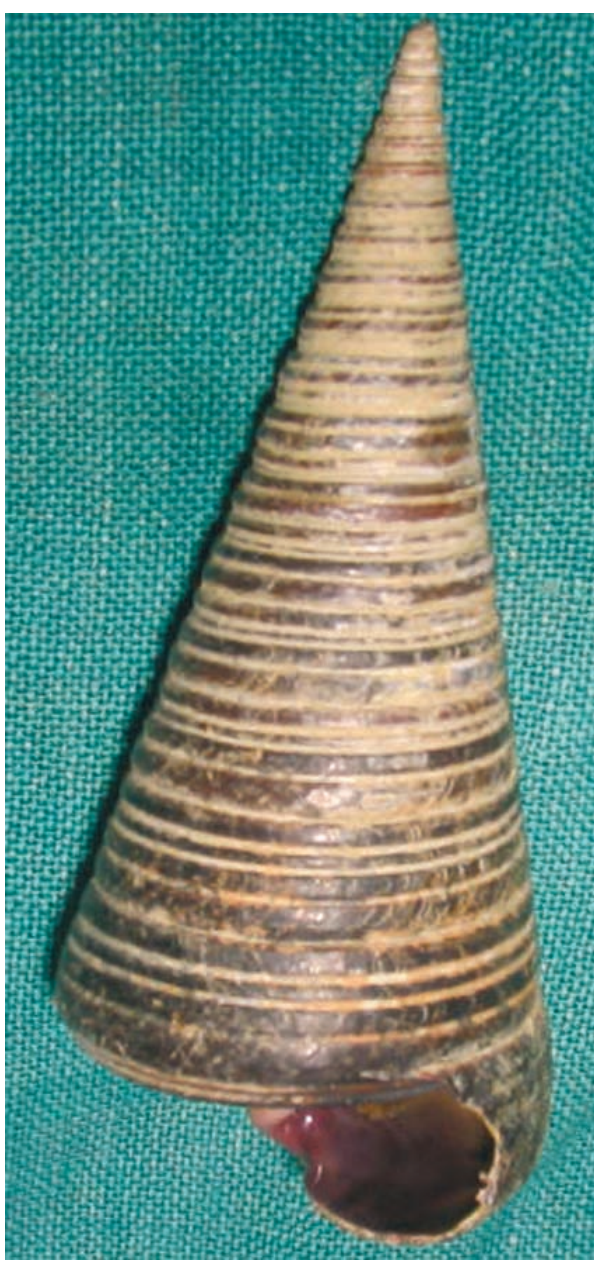

Fig. 1. Photograph of the snail Telescopium telescopium with shell.

The taxonomical position of this mangrove snail Telescopium telescopium under investigation is as follows:

Kingdom: Animalia; Subkingdom: Metazoa; Phylum: Mollusca; Sub phylum: Conchifera; Class: Gastropoda (univalve: orthogastropoda); Superorder: Caenogastropoda; Order: Sorbeoconcha; Super family: Cerithiacea; Family: Potamididae; Genus: Telescopium; species: telescopium.

Preparation of the spermatheca/ ovotestis gland cytosol fraction. After thorough washing with distilled water, the shells of the snail's were broken carefully with a hammer. Each spermatheca/ovotestis gland was dissected free from the snail's body and were minced carefully in a Petri dish and homogenized with 4 volume of $0.5 \mathrm{M}$ phosphate buffer saline (PBS), $\mathrm{pH} 7.2$ at $40 \mathrm{C}$ in a motor driven Teflon dounch homogenizer (Remimotors, Mumbai 53, India). The grinded tissue fragmented further by sonicator at $00 \mathrm{C}$ environment with a Brownwill Biosonic IV, VWR sonicator (Scientific, Sanfrancisco, CA), set at $100 \%$ output for four 15 -s brusts at $\geq 30$-s interval for a total period of 1 h. The sonicated material was spun in a Beckman SW 28 swinging bucket rotor at $15,000 \mathrm{~g}$ for $30 \mathrm{~min}$ at $4 \mathrm{OC}$ to discard the cell debris. Cytosol fraction (MBC) was collected carefully from each centrifuge tube by sterilize Pasteur pipette and kept in sterilized test tubes. The MBC was passed through membrane filter and was lyophilized (VIRTIS; Genesis $25 \mathrm{EL}$ ), and kept at $-200 \mathrm{C}$ in sealed polysterene containers till further use.

Biochemical estimation of the cytosol fraction. Biochemical analysis of the lyophilized cytosol fraction was estimated for acid phosphatase (ACP) and alkaline phosphatase (AKP) as described by Tietz et al. (1995) by commercial kit (Chemelex, S.A. Poligono Industrial Can Castells. C/ Industria 113 Nave J, 08420 Cannovelles-Barcelona). Lactic dehydrogenase (LDH) content was determined by photo electric colorimeter (Bergmeyer, 1965) (Reckon Diagnostic P Ltd, 3/7 Industrial Estate, Baroda, India). Estimation of lipase (Lott et al., 1986) and creatinine phosphokinase (CPK; Szasz et al., 1976) was performed with the kits (Diasis Diagnostik Sistemler Tic Ve San. A. S. Okmeydani-Istanbul, Turkey; Radox Laboratories Ltd. Antrim, UK; Invitro Biotech Ltd., Hyderabad, India and Crest Biosystems, Goa, India respectively). Serum glutamic pyruvic transaminase (SGPT), Serum glutamic oxaloacetic transaminase (SGOT) and gamma gluteryl transferase (GGT) was estimated according to IFCC methods (1986). Determination of quantity of chloride (Schoenfeld \& Leweller, 1964), Albumin (Doumas et al., 1972), HDLCholesterol (Burstein et al., 1970), Triglycerides (Schettler \& Nussel, 1975), Creatinine (Fabing \& Ertingshausen, 1971), Glucose (Tietz, 1982), Iron (Siedel et al., 1984) Magnesium (Whitmore \& Evans, 1964), Copper \& Zinc (Agarwal \& Henkin, 1985), Lithium (Vonknoring et al., 1976), Total protein (Doumas et al., 1975), Urea (Fawcett \& Scott, 1960), Inorganic phosphorus (Amador \& Urban, 1977) and Bicarbonate (Tietz, 1976) were also estimated by kits (Bayer Diagnostics India Ltd. Gujrat, India; Erba Diagnostics Mannheim GmbH, Germany; Reckon Diagnostic P. Ltd., 3/ 7 industrial estate, Baroda , India; Merck Limited, Worli, Mumbai, India; Invitro Biotech Ltd., Hyderabad, India; Crest Biosystems, Goa, India); Estimation of hormonal levels, if any, were also determined for Testosterone (Ismail et al., 1972), Insulin (Eastham, 1985), thyroid stimulating hormone (TSH) (Spencer, 1995), Estradiol and Progesterone (Tietz, 1986) (Equiper via G Ferrari, Italy, Monobind Inc. Lake forest, CA, USA both for insulin and TSH and DRG Instruments GmbH, Germany for estradiol and progesterone respectively).

Study of the spermatozoan morphology. To study the spermatozoan morphology and its structure, two spermatheca/ovotestis glands were minced in a Petri dish containing $1 \mathrm{ml}$ of milipore filter sea water (MFSW). Minced tissues were squeezed gently and filtered through nitex membrane $(150 \mu \mathrm{m}$ pore size). Filtered sperm suspension was kept in a sterile container and incubated at $37{ }^{\circ} \mathrm{C}$ in an incubator providing $5 \% \mathrm{CO}_{2}$ in air. Immediately before incubation $10 \mu \mathrm{l}$ of sperm suspension was placed onto microscopic glass slide, covered with cover slip and observed under Leitz phase contrast microscope (x 1000). 
To measure the sperm cell, $10 \mu \mathrm{l}$ of the incubated sperm suspension was placed onto two microscopic glass slides, air dried and fixed for two min with $4 \%$ formalin prepared in MFSW. Fixed smears were washed into PBS and stained for $1 \mathrm{~min}$ with $0.01 \%$ trypan blue prepared in MFSW. Stained slides were washed sequentially by two single dips into distilled water and air dried. Measurements of the sperm cells were made by ocular micrometer under the microscope (x 1000) and the mean values were expressed in $\mu \mathrm{m}$.

For scanning electron microscopy (SEM), incubated sperm suspension was centrifuged twice at $500 \mathrm{~g}$ for 10 min in MFSW discarding supernatant each time. Sperm pellet was fixed overnight at $4{ }^{\circ} \mathrm{C}$ with $2.5 \%$ gluteraldehyde prepared in MFSW. Once fixed, the sperm pellet was washed twice in $0.15 \mathrm{M}$ PBS, pH 7.4 by centrifugation as above and supernatant was discarded each time. Finally, the sperm pellet was dehydrated through a graded ethanol series followed by in isoamyl acetate respectively. Critical point dehydration was performed in Hitachi HCP-1 for 1 h. After dehydration the sperm pellet was coated with gold in a vacuum evaporator and examined under JEOL U3 SEM (Hodson \& Bernard, 1986).

For transmission electron microscopy (TEM), small portion of the reproductive gland was excised by a sharp razor from the spermatheca/ovotestis gland and placed directly into $2.5 \%$ gluteraldehyde, buffered with $0.2 \mathrm{M}$ Na-cacodylate, $\mathrm{pH} 7.4$ for $2 \mathrm{~h}$ at $4{ }^{\circ} \mathrm{C}$. The fixed tissue was cut in $2 \mathrm{~mm}$ square approximately $1 \mathrm{~mm}$ thick and fixed again as before for $1 \mathrm{~h}$. After fixation the tissue was washed in two changes of $0.2 \mathrm{M} \mathrm{Na}$-cacodylate buffer, $\mathrm{pH} 7.4$ for 15 min each and post fixed into $1 \%$ Osmium tetraoxide (OsO4) in $0.1 \mathrm{M}$ sodium-cacodylate buffer for $1 \mathrm{~h}$ at $4{ }^{\circ} \mathrm{C}$. Fixed tissue was allowed to dehydrate with graded ethanol and acetone series respectively and embedded in EPON. Ultra thin sections $(60 \mathrm{~nm})$ were cut on a MT 2B ultramicrotome with a diamond knife and picked-up on 150 Mesh copper grids. The sections were stained as follows: Filtered uranyl acetate solution, $5 \mathrm{ml}$ was taken into a watch glass and the copper grids carrying the sections were placed into the stain for $15 \mathrm{~min}$ in a dark place. Each grid then washed sequentially twice into $50 \%$ ethanol followed by distilled water with continuous gentle agitation. The sections were dried carefully on a filter paper and placed again into a watch glass containing $5 \mathrm{ml}$ of lead citrate solution for $10 \mathrm{~min}$. After staining, the sections were washed by two single dips into distilled water containing 2 drops of $0.1 \mathrm{M} \mathrm{NaOH}$ solution and washed finally into distilled water for $1 \mathrm{~min}$. The grids with stained sections were dried on the filter paper and examined under Philips EM 410 (Sousa et al., 1989).
Preparation of human sperm antigen (HSA). Fresh, normal and proven human semen samples were collected into sterile test tubes following masturbation. Samples were allowed to liquefy for $45 \mathrm{~min}$ in an incubator at $370 \mathrm{C}$. After liquefaction semen samples were pooled and centrifuged for $15 \mathrm{~min}$ at $500 \mathrm{~g}$. The seminal plasma was discarded and 2 $\mathrm{ml}$ of $0.15 \mathrm{M}$ PBS (pH 7.4) was mixed with the sperm pellet and vortexed gently. Sperm suspension was filtered through nitex membrane and centrifuged again as above. Supernatant was discarded. Finally, sperm pellet was resuspended with $2 \mathrm{ml}$ of $1 \%$ sodium Dodecyl sulphate (SDS; SIGMA) and $0.2 \mathrm{mM}$ phenyl-methyl-sulfonyl fluoride (PMSF; SIGMA) in $0.15 \mathrm{M} \mathrm{PBS}$ and allowed to freeze at $-200 \mathrm{C}$ for overnight. The suspension then allowed to melt at $4{ }^{\circ} \mathrm{C}$, and sonicated as before. Sonicated material was centrifuged at $10,000 \mathrm{~g}$ for $1 \mathrm{~h}$. The sperm cytosol fraction was aspirated carefully by micropipettes, kept in sterilized test tubes and stored at $200 \mathrm{C}$ till experimentation.

Preparation of spermatheca / ovotestis antiserum (ARS). Lyophilized "MBC", $100 \mathrm{mg}$, was dissolved into $5 \mathrm{ml}$ of $0.5 \mathrm{M}$ PBS (pH 7.2) and emulsified in a sterile glass beaker with $10 \mathrm{ml}(1: 2)$ of Freund's complete adjuvant (FCA) at 4 $0 \mathrm{C}$ by a $10 \mathrm{ml}$ glass syringe with luer lock. Similarly $0.5 \mathrm{M}$ PBS (pH 7.2), $5 \mathrm{ml}$ and FCA, $10 \mathrm{ml}$ (1:2) was prepared for the control run.

To obtain the anti-MBC- rabbit serum (ARS), emulsified antigen (MBC: FCA), $0.5 \mathrm{ml}$ was inoculated subcutaneously by a tuberculin syringe into each experimental rabbit of Group I (3 rabbits), at 10 different sites in the lower back region. Further inoculation was done on every 3 days apart with the same dose. The animals were allowed to receive the antigen for 6 occasions and booster dose was given intraperitoneally to each rabbit with $2 \mathrm{ml}$ of this emulsion. Rabbits of Group II ( 3 rabbits), as control animals, PBS: FCA (1:2) emulsion was inoculated as above schedule to obtain the control rabbit serum (CRS).

Blood samples were collected from all the immunized rabbits by heart puncture (Herbert, 1979) with individual glass syringe, 7 days after the booster dose. Blood samples were kept into separate sterile test tubes in slanting position at room temperature for $1 \mathrm{~h}$ to allow the samples to clot. The samples were allowed to retract by keeping the test tubes at $40 \mathrm{C}$ for 4 $\mathrm{h}$ and centrifuged at $1000 \mathrm{~g}$ for $15 \mathrm{~min}$. Serum samples were collected carefully from each tube by separate Pasteur pipettes. All the serum samples i.e., CRS and ARS were pooled individually into sterile glass test tubes. To inactivate the complements, all the serum samples were decomplemented at $56{ }^{\circ} \mathrm{C}$ for $30 \mathrm{~min}$ in a water bath and cooled at room temperature. Decomplemented, CRS and ARS samples were aliquoted and kept at $-20{ }^{\circ} \mathrm{C}$ after proper coding. 


\section{Enzyme linked electro-immunotransfer blot.}

SDS-PAGE. Cytosol fraction of human sperm, $25 \mu 1$, was solubilized with an equal volume of sample buffer in a test tube and was heated in boiling water bath at $1000 \mathrm{C}$ for 3 min electrophoresis was carried out at $4{ }^{\circ} \mathrm{C}$ with $100 \mathrm{~V}$, according to SDS-discontinuous system (Laemmli, 1970) on $10 \%$ polyacrylamide gel (SDS-PAGE; $1.5 \times 180 \times 200$ $\mathrm{mm}$ ) with $50 \mu \mathrm{l}$ of this prepared solution. Molecular weight markers (BIORAD) were also run side by side.

WESTERN-BLOTTING. Nitrocellulose membranes (NCM, $0.45 \mu \mathrm{m}$ pore, SIGMA) and whatman filter papers number 3 were cut in appropriate size. After completion of SDS-PAGE run, gel was separated from the glass slabs. All the NCM, filter papers and the gel was allowed to soak in transfer buffer (Tris-glycine buffer), $\mathrm{pH}$ 8.3. The gel was transferred along with wet filter papers on the supporting pads toward cathode and the gel surface was rinsed with 10 $\mathrm{ml}$ of transfer buffer. The NCM sheet was placed directly on the gel surface on anode side. Filter papers were placed separately on the NCM sheet carefully and the cassettes were closed. The assembled cassettes were transferred to pre cooled transfer buffer into the buffer tank in a transblot apparatus (Hoefer Transphor apparatus; Hoefer Scientific Instruments, San Fransisco, CA) $50 \mathrm{v}$ of current was passed for $3 \mathrm{~h}$ at $4{ }^{\circ} \mathrm{C}$ (Towbin et al., 1979; Towbin \& Gordon, 1984).

IMMUNOBLOTTING. After $3 \mathrm{~h}, \mathrm{NCM}$ was removed from the cassettes and placed into glass tray containing $200 \mathrm{ml}$ of washing buffer (tris buffer saline, $0.01 \mathrm{M}$ ) pH 7.2, and washed with gentle shaking for $15 \mathrm{~min}$ with two changes in washing buffer, NCM sheet was treated separately with 100 $\mathrm{ml}$ of blocking buffer, $\mathrm{pH} \mathrm{7.4,} \mathrm{for} 1 \mathrm{~h}$ at room temperature

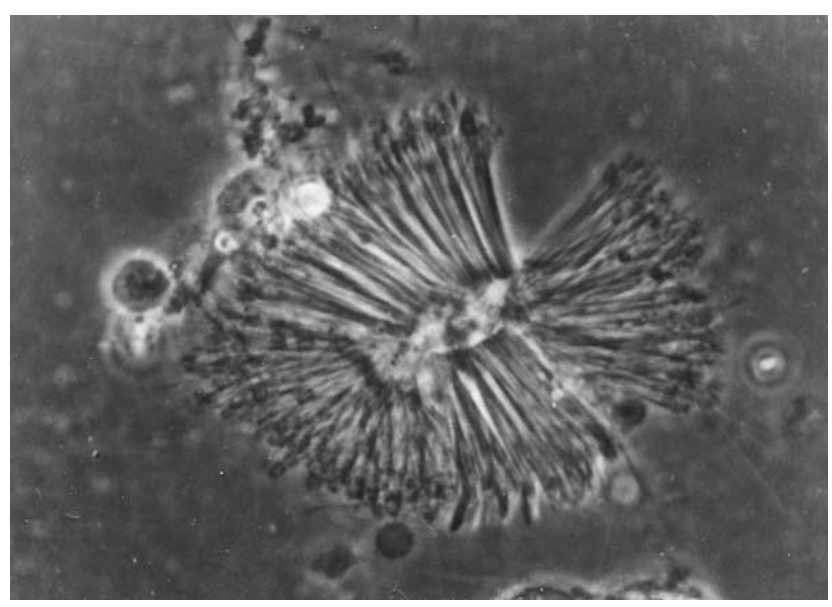

Fig. 2. Microphotograph of Telescopium telescopium sperm tails attached with gelatinous mass (x 1000). with continuous agitation on gel shaker to block the nonspecific sites and the solution was discarded. ARS was diluted into washing buffer (1:100), overlaid on the NCM sheet and incubated for $2 \mathrm{~h}$ at room temperature with continuous agitation. After incubation the primary antibody (ARS) was discarded and NCM sheet was washed again by washing buffer with gentle agitation as before for 5 times with a gap of 10 min between each wash. After washing NCM sheet was incubated with goat-anti rabbit-IgG conjugated to Horseradish peroxidase (HRP; SIGMA) diluted in washing buffer (1: 100) for $1 \mathrm{~h}$ at room temperature. The solution was discarded again and the sheet was washed as before in the washing buffer.

SUBSTRATE REACTION. After discarding washing buffer, freshly prepared Diaminobenzidine (DAB) solution $\mathrm{pH}$ 7.2 (50 mg DAB dissolved in $100 \mathrm{ml}$ of washing buffer and filtered. $40 \mu \mathrm{l}$ of $30 \% \mathrm{H}_{2} \mathrm{O}_{2}$ was mixed) and overlaid on NCM sheet (Sternberger, 1969) and shaked gently. Ag: Ab reaction was monitored visually until insoluble brown colour complex on the protein blot was appeared and washed the sheet immediately with tap water to stop the reaction followed by a single dip into the distilled water. The NCM sheet was dried on gel and photographed. Similarly immunoblotting was also performed with CRS.

\section{RESULTS}

Immediate microscopical observation of the sperm suspension revealed that sperm tails were held together in a gelatinous mass and free heads were propelled vigorously (Fig. 2). The cells ultimately detached and swim away from the gelatinous mass. Free sperm cells had whiplash like movement into the medium. Total length of the sperm and it's head was about $50 \mu \mathrm{m}$ and $3.6 \mu \mathrm{m}$ respectively. Observation by SEM revealed Telescopium telescopium sperm comprises of three regions- head, short midpiece and a long tail (Fig. 3). The sperm axonemal microtubules had "9+2" arrangement as observed by TEM (Fig. 4).

So far the biochemical nature of spermatheca/ ovotestis gland cytosol fraction was analyzed, it exhibited a wide range of biogenic compounds remain in this tiny gland (Table I).

Analysis of human sperm extract (HSA) by immunoblot showed that, ARS was able to cross-react with the HAS polypeptide bands with an apparent molecular weight at 84, 78, 55, 47, 37 and $23 \mathrm{KD}$ respectively, however, CRS was non reactive. 


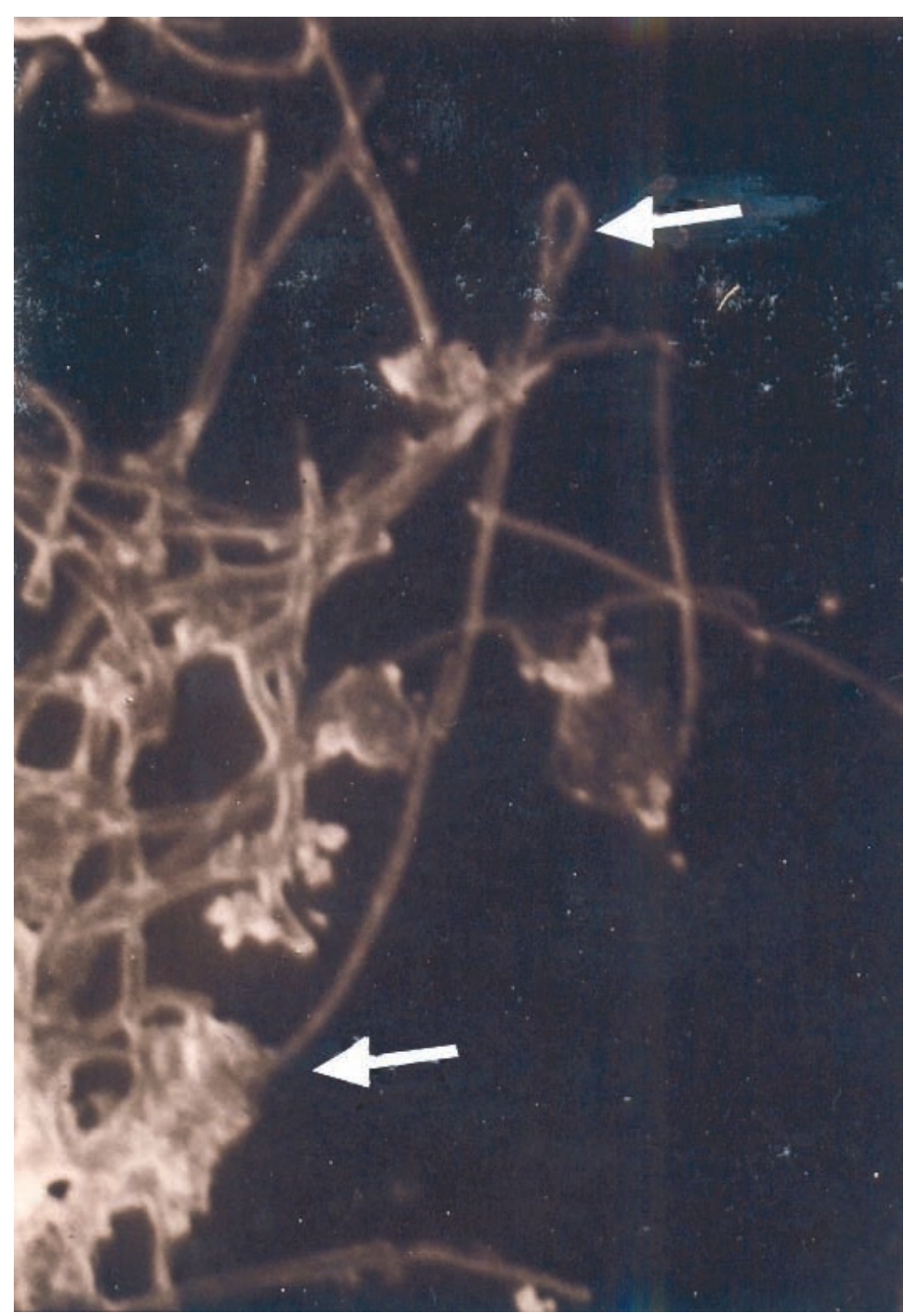

Fig. 3. Electronmicrograph of Telescopium telescopium sperm (SEM, $x$ $15,000)$

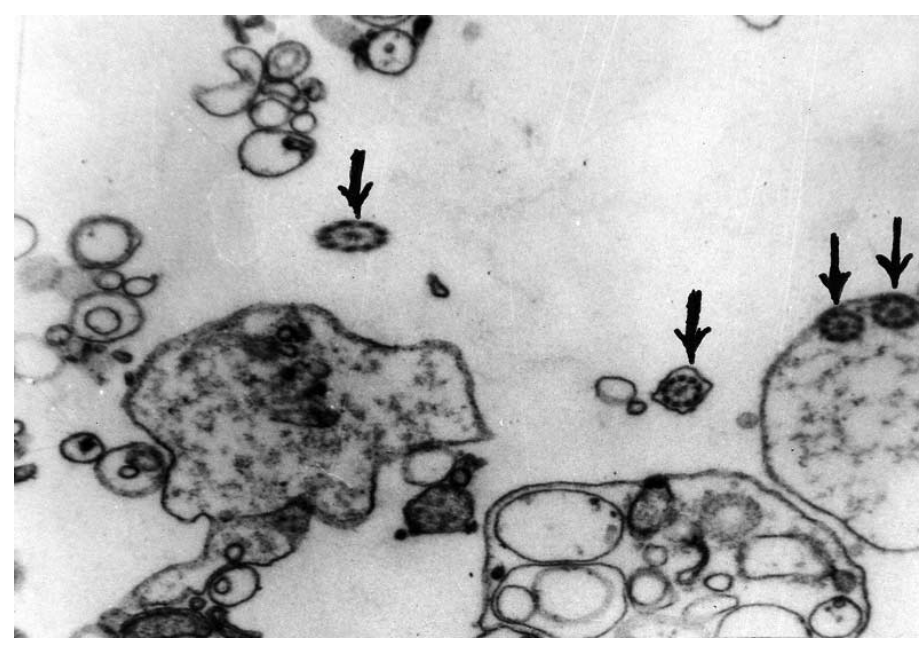

Fig. 4. Electronmicrograph of Telescopium telescopium sperm showing "9+2" arrangement in the axial filament (TEM, x 62,500).
Table I. Biochemical composition of the Spermatheca/ ovotestis gland from Telescopium telescopium.

\begin{tabular}{|c|c|c|}
\hline SL. $\mathrm{N}^{\circ}$ & Composition & Concentration \\
\hline 1 & $\mathrm{ACP}$ & $10 \mathrm{IU} / \mathrm{L}$ \\
\hline 2 & AKP & $179 \mathrm{IU} / \mathrm{L}$ \\
\hline 3 & $\mathrm{CPK}$ & $2.0 \mathrm{IU} / \mathrm{L}$ \\
\hline 4 & GGT & $16.0 \mathrm{IU} / \mathrm{L}$ \\
\hline 5 & SGPT & $148 \mathrm{IU} / \mathrm{L}$ \\
\hline 6 & SGOT & $352 \mathrm{IU} / \mathrm{L}$ \\
\hline 7 & $\mathrm{LDH}$ & $17 \mathrm{IU} / \mathrm{L}$ \\
\hline 8 & Lipase & $29.0 \mathrm{IU} / \mathrm{L}$ \\
\hline 9 & Amylase & $2.0 \mathrm{IU} / \mathrm{L}$ \\
\hline 10 & Insulin & $6.2 \mu \mathrm{IU} / \mathrm{ml}$ \\
\hline 11 & TSH & $0.05 \mu \mathrm{IU} / \mathrm{ml}$ \\
\hline 12 & Estradiol & $201 \mathrm{pg} / \mathrm{ml}$ \\
\hline 13 & Testosterone & $1.75 \mathrm{ng} /$ \\
\hline 14 & Progesterone & $5.0 \mathrm{ng} / \mathrm{ml}$ \\
\hline 15 & Vitamin B12 & $1504.0 \mathrm{pg} / \mathrm{ml}$ \\
\hline 16 & Creatinine & $0.2 \mathrm{mg} / \mathrm{dl}$ \\
\hline 17 & Cholesterol & $38 \mathrm{mg} / \mathrm{dl}$ \\
\hline 18 & Triglycerides & $34 \mathrm{mg} / \mathrm{dl}$ \\
\hline 19 & HDL & $8 \mathrm{mg} / \mathrm{dl}$ \\
\hline 20 & Urea & $12 \mathrm{mg} / \mathrm{dl}$ \\
\hline 21 & Inorganic phosphorus & $0.96 \mathrm{mg} / \mathrm{dl}$ \\
\hline 22 & Magnesium & $10.6 \mathrm{mEq} / \mathrm{L}$ \\
\hline 23 & Lithium & $0.4 \mathrm{mEq} / \mathrm{L}$ \\
\hline 24 & Potassium & $4.5 \mathrm{mEq} / \mathrm{L}$ \\
\hline 25 & Sodium & $82 \mathrm{mEq} / \mathrm{L}$ \\
\hline 26 & Iron & $212 \mu \mathrm{g} / \mathrm{dl}$ \\
\hline 27 & Copper & $55 \mu \mathrm{g} / \mathrm{dl}$ \\
\hline 28 & Zinc & $42 \mu \mathrm{g} / \mathrm{dl}$ \\
\hline 29 & Chloride & $8 \mathrm{mEq} / \mathrm{L}$ \\
\hline 30 & Bicarbonate & $12 \mathrm{mEq} / \mathrm{L}$ \\
\hline 31 & Glucose & $25 \mathrm{mg} / \mathrm{dl}$ \\
\hline 32 & Total protein & $286 \mathrm{mg} / \mathrm{dl}$ \\
\hline 33 & Albumin & $180 \mathrm{mg} / \mathrm{dl}$ \\
\hline 34 & Globulin & $106 \mathrm{mg} / \mathrm{dl}$ \\
\hline 35 & Non Protein Nitrogen & $1.7 \mathrm{mg} / \mathrm{dl}$ \\
\hline
\end{tabular}




\section{DISCUSSION}

Evolution provides a vast and well-chosen body of evidence showing that existing animals and plants cannot have been separately created in their present forms, but must have evolved from earlier forms by slow transformation. And by the natural selection, such transformation could and would automatically be produced, and all living organisms must be related through their common descent from some simple original stock (Darwin, 1859). Therefore, phylogenetic study plays an important role to evaluate different yet related forms of the same molecules involved in similar physiological, biochemical and immunological roles which can give evolutionary ideas of basic molecular mechanisms e.g. intermolecular and intramolecular cooperativity, modulation of intermolecular heterogeneity, active site functions, immunobiological functions, adaptive functions and the nature of carbohydrate present on the cell surfaces (Litman, 1976). Hence, phylogenetic study provides various important informations on the origin, development, nature and interactions of various cells type including their architectures also.

Ottaviani (2004) opined that the same and relatively similar molecules seen in molluscan defense responses are also found in mammals, where their functions remain basically similar. The similarities have been observed in the immune and neuroendocrine mechanisms between invertebrates and mammals. Cytokine-Im are present in the molluscan haemolymph, immunocytes and nervous system and they seem to act in similar ways with identical effects both in molluscan and human immunocytes. Parallelism between mammals and invertebrates are also found in stress response where invertebrates as mammals present a bidirectional interaction between the immune and neuroendocrine systems (Blalock, 1989). Similar biological mechanisms of adrenocorticotropin hormone (ACTH) action have been found both in molluscan and human immunocytes in Schistosomiasis (Duvaux-Miret et al., 1992). In human immunodeficiency virus (HIV), ACTH immunomodulation with the same characteristics in both molluscan immunocytes and human granulocytes have been observed. HIV induces the production of ACTH and melanocyte stimulating hormone (MSH) by H9 T-lymphomacells. These peptides provoke the deactivation of granulocytes in $2 \mathrm{~h}$ by ACTH and in $20 \mathrm{~min}$. by MSH. Tantamount experiment with molluscan immunocytes revealed superimposed response by ACTH and MSH (Smith et al., 1992).

The antibody raised against spermatheca/ ovotestis gland cytosol fraction (ARS) exhibited positive reaction with human sperm antigen (HAS) in immunoblot analysis. This indicated presence of cross-reactivity, species-specificity and homogeneity between the ARS and HAS, as well as both the antigens were related immunogenically. Lopo \& Vacquier (1980) also observed sea urchin sperm specific antigen(s) cross reacted with the sperm of 28 species from 7 animal phyla including aves and mammalia. Importantly, this crossreactivity suggests that basic pattern of protein molecules involved possess some common sperm specific carbohydrate sequences indicating presence of similar antigenic determinants in between Telescopium telescopium and human which are retaining through phylogenetic evolution.

Above observations thus support that the cells of the immune systems are probably derived from the primitive cellular defense mechanisms, which arose with the evolution of invertebrates, and the basic pattern of the protein molecules involved has been retained with the diversification that has occurred through the evolutionary selective pursuance. This simplest manifestation of immunity has been found throughout the phylogenetic sequences, and each therefore, possess remnants of the successive steps in the development of immunity in both the ontogenetic and phylogenetic development of animal species in stepwise, ordered fashion (Cooper, 1971; 1973).

Present investigation also revealed that different biomolecules e.g. enzymes, hormones, trace elements, vitamin which present in the spermatheca/ovotestis gland as well as " $9+2$ " arrangement in the sperm microtubules from Telescopium telescopium are also remaining in the human body and in their sperm (Fawcett \& Bedford, 1979; Dustin, 1984) indicating plausible existence of phylogenetic relationship between mollusc and mammals.

Therefore, this experiment plausibly supports that relatively similar molecules and their basic physiological functions in molluscan system may remain the same in vertebrates regardless structural changes of these ancestral biomolecules, (Ottaviani; Halvey, 1990), as also found by Kemenes (2005) that brain molecules in humans and pond snails actually share important characters unchanged by evolution.

The hypothesis of our observation could be explained as -"Evolution that started on planet earth millions of years ago through the formation of life from a tiny single cell to super ape through various environmental, physical, biophysical, chemical, biochemical and structural changes yet there remain some relationship amongst these distant species", which also support the view of Gould (1977), that 
"Evolution occurs when ontogeny is altered in one or two ways: when new characters are introduced at any stage of development with varying effects upon subsequent stages, or when characters already present undergo changes in developmental timing. Together, these two processes exhaust the formal content of phyletic change."
We may conclude from this simple experiment that a conserved set of molecules which involve in different physiological, biochemical and immunological functions in mollusc, possibly sharing similar needs in different form (shape) of the same molecule(s) to play common function (s) in mammals even after evolution.

DATTA, U.; HEMBRAM, M. L.; ROY, S. \& MUKHERJEE, P. Morfología de los espematozoides y biomoléculas naturales del caracol marino Telescopium telescopium: una perspectiva filogenética. Int. J. Morphol., 28(1):175-182, 2010.

RESUMEN: El análisis bioquímico de la fracción aislada del citosol desde las glándulas ovotestes/espermateca del molusco marino Telescopium telescopium y su estructura tubular espermática revelaron biomoléculas relativamente similares como tales como diferentes enzimas, hormonas, minerales y estructuras de los espermatozoides que también existen en los seres humanos. Por otra parte, en el antisuero de la fracción citosólica se encontró una reacción cruzada con los antígenos del esperma humano indicando la presencia de una superficie espermática de antigenicidad común entre estas dos diversificadas especies. Estos hallazgos pueden apoyar y/o hipotetizar sobre el origen y la diversificación de las moléculas de los vertebrados desde su forma (s) ancestral desde los invertebrados, y funciones básicas fisiológicas de estas biomoléculas ancestrales incluyendo algunas de las estructuras celulares siendo plausiblemente las mismas, independientemente de sus cambios estructurales incluso después de la evolución.

\section{PALABRAS CLAVE: Filogenia; Telescopium telescopium; Biomoléculas; Espermatozoide; Mamífero.}

\section{REFERENCES}

Agarwal, R. \& Henkin, R. A simple method for simultaneous estimation of zinc and copper in erythrocytes. Biol. Trace Element Res., 7(4):199-208, 1985.

Amador, E. \& Urban, J. Simplified serum phosphorus analysis by continuous flow UV spectrophotometry. Clin. Chem., 18:60, 1977.

Bergmeyer, H. U. Methods of Enzymatic Analysis. $2^{\text {nd }}$ Ed. London, Academic Press, 1965.

Blalock, J. E. A molecular basis for bidirectional communication between the immune and neuroendocrine systems. Physiol. Rev., 69(1):1-32, 1989.

Burstein, M.; Scholnick, H. P. \& Mortin, R. Cholesterol in High Density Lipoprotein: using Mg++/PTA. J. Lipid Res., 19:563, 1970.

Cooper, E. L. Phylogeny of transplantation immunity. Graft rejection in earthworms. Transpl. Proc., 3:214-20, 1971.

Cooper, E. L. Earthworm coelomocytes: Role in understanding the evolution of cellular immunity. I. Formation of monolayers and cytotoxicity. Proc. III International Colloquim of Invertebrate Tissue Cultures. Rehacek, J.; Blaskovic, D. \& Hink, W. F. (Eds.). Bratislava, Publishing House of the Slovac Academy of science, 1973. pp.381-404.

Darwin, C. The origin of Species. $6^{\text {th }}$ Ed. New York and Scarbrough, New American Library, 1859.

Doumas, B. T.; Arends, R. L. \& Pinto, P. C. Standard Methods of Clinical Chemistry. Chicago, Academic Press, 1972. pp.175-89.
Doumas, B. T.; Peters, T. J. \& Bio-monle, G. T. Protein (Total protein) in serum, urine, and cerebrospinal fluid. In: Faulkner, W. R. \& Meites, S. (Ed.). Selected methods of clinical chemistry. Washington, AACC, 1975. pp.822-8.

Dustin, P. Microtubules. Heidelberg, Springer-Verlag, 1984.

Duvaux-Miret, O.; Stefano, G. O.; Smith, E. M.; Dissous, C. \& Capron, A. Immunosuppression in the definitive and intermediate hosts of the human parasite Schistosoma mansoni by release of immunoactive neuropeptides. Proc. Natl. Acad. Sci., 89:778-81, 1992.

Eastham, R. D. Biochemical values in Clinical Medicines. 7. Ed. London, John Wright and Sons Ltd., 1985. pp.140-5.

Fabing, D. L. \& Ertingshausen, G. Automated reaction-rate method. for determination of serum creatinine with centrifichem. Clin. Chem., 17:391, 1971.

Fawcett, D. W. \& Bedford, J. M. The spermatozoon Maturation, Motility, Surface properties and Comparative Aspects. London, Urban and Schwarzenberg, 1979.

Fawcett, J. K. \& Scott, J. E. A rapid and precise method for the determination of urea. J. Clin. Pathol., 13:156, 1960.

Franzen, Å. Phylogenetic aspects of the morphology of spermatozoa and spermiogenesis, In: Bacetti, B. (ed.), Comparative Spermatology, New York, Academic Press, 1970. pp.29-46.

Franzen, A. Sperm structure with regard to fertilization, biology and phylogenetics. Verh. Dtsch. Zool. Ges., 19:123-8, 1977. 
Franzen, Å. Ultrastructural studies of spermatozoa in three bivalve species with notes on evolution of elongated sperm nucleus in primitive spermatozoa. Gamete. Res., 7:199-214, 1983.

Gould, S. J. Ontogeny and Phylogeny. Cambridge, Belknap Press, 1977.

Halvey, S. Microbiology: Application in food Biotechnology. New York, Elsevier Applied Science Press, 1990.

Herbert, D. J. Laboratory animal techniques for Immunology. In: Handbook of Experimental Immunology, Application of immunological Methods. Weir, D. M. (ed.). Oxford, Blackwell Scientific Publications, 1979.

Hodson, A. N. \& Bernard, R. T. F. Ultrastructure of the sperm and spermatogenesis of three species of Mytilidae (Mollusca, Bivalvia). Gamete Res., 15:123-35, 1986.

IFCC. Method for aspartate aminotransferase (L-aspartate: 2oxoglutarate aminotransferase, EC 2.6.1.1).J. Clin. Chem. Clin. Biochem., 24:497-510, 1986.

Ismail, A. A.; Niswender, G. D. \& Midgley, A. R. Radioimmunoassay of testosterone without chromatography. J. Clin. Endocr. Metab., 34:177-84, 1972.

Kemenes, G. Snail's set the pace in human memory loss research. Avalaible in:http://www.medicalnewstudy. com, 2005.

Laemmli, U. K. Cleavage of structural proteins during the assembly of the head of bacteriophase-T-4. Nature, 227:680-5, 1970.

Litman, G. W. Physical properties of immunoglobulins of lower species: A comparison with immunoglobulins of Mammals. In: Marchalonis J. (ed.), Comparative Immunology. Oxford, Blackwell Scientific Publications, 1976. pp.239-97.

Lopo, A. C. \& Vacquier, V. D. Sperm-specific surface antigenicity common to seven animal phyla. Nature, 288:397-9, 1980.

Lott, J. A.; Patell, S. T.; Sawhney, A. K.; Katzmierczack, S. C. \& Love, J. E. (Jr.). Assay of serum lipase: Analytical and Clinical considerations. Clin. Chem., 32:1290-302, 1986.

Ottaviani, E. The mollusc as a suitable model for mammalian immuno-neuroendocrine investigations. Inv. Surv. J., 1:2-4, 2004.

Popham, J. D. Comparative spermatozoon morphology and bivalve phylogeny. Malac. Rev., 12:1-20, 1979.

Schettler, G. \& Nussel, E. Enzymatic calorimetric determination of high density lipoprotein cholesterol by CHOD-PAP method. Arb. Med. Soz. Med. Prov. Med., 10:25, 1975.

Schoenfeld, R. G. \& Lewellen, C. J. A colorimetric method for determination of serum chloride. Clin. Chem., 10:533-9, 1964.

Siedel, J.; Wahlefeld, A. W. \& Ziegenhorn, J. A new iron ferrozinereagent without deproteinisation. Clin. Chem., 30:975, 1984.
Smith, E. M.; Huges, T. R. Jr.; Hashemi, F. \& Stefano, G. B. Immunosuppressive effects of corticotrophin and melanotropin and their possible significance in human immunodeficiency virus infection. Proc. Natl. Acad. Sci., 89:782-6, 1992.

Sousa, M.; Corral, L. \& Azevedo, C. Ultrastructural and cytochemical study of spermatogenesis in Scrobicularia plana (Mollusca, Bivalvia). Gamete Res., 24:393-401, 1989.

Spencer, C. A. Interlaboratory/ Intermethod differences in functional sensitivity of immunometric assay of thyrotropin (TSH) and impact on reliability of measurement of subnormal concentrations of TSH. Clin. Chem., 41:367-70, 1995.

Sternberger, L. A. Immunocytochemistry. $2^{\text {nd }}$ Ed. New York, John Wiely and Sons, 1969. pp.129-71.

Szasz, G.; Gruber, W. \& Bernt, E. Creatinine Kinase in serum: 1. Determination of optimum reaction conditions. Clin. Chem., 22:650-6, 1976.

Tietz, N. W. Electrolytes, In: Fundamentals of Clinical Chemistry. 2nd Ed. Philadelphia, W. B. Saunders Co., 1976. pp.873-944.

Tietz, N. W. Renal function, In: Fundamentals of Clinical Chemistry. $2^{\text {nd }}$ Ed. Philadelphia, W. B. Saunders Co., 1982. pp.280-9.

Tietz, N. W. Text Book of Clinical Chemistry. Philadelphia, W. B. Saunders Co., 1986. pp.960-2.

Tietz, N. W. Clinical Guide to Laboratory Tests. $3^{\text {rd }}$ Ed. Philadelphia, W. B. Saunders Co., 1995. pp.216-7.

Towbin, H. T.; Stachelin, T. \& Gordon, J. Electrophoretic transfer of proteins from poly acrylamide gels to nitrocellulose sheets: procedure and some applications. Proc. Nat. Acd. Sci., 76:43504, 1979.

Towbin, H. T. \& Gordon, J. Immunoblotting and dot immunoblotting, Current status and outlook. J. Immunol. Methods, 72:313-40, 1984.

Vonknoring, L.; Oriland, L.; Perris, C. \& Runebery, S. Lithium RBC/ Plasma ratio in subgroups of patients with affective disorders. Neuropsychobiology, 2:74-80, 1976.

Whitmore, D. N. \& Evans, D. I. K. An automated method for serum magnesium estimation. J. Clin. Pathol., 17:644-8, 1964.

\section{Correspondence to:}

Dr. Uttam Datta, M.V.SC, Ph.D.

Department of Veterinary Gynaecology \& Obstetrics

Faculty of veterinary and animal science

West Bengal University of Animal and Fishery Sciences

37 and 68, Kshudiram Bose Sarani, Belgachia

Kolkata-700037, West Bengal

INDIA

E-mail: uttamdtt@yahoo.com

Received: 29-04-2009

Accepted: 13-12-2009 